\title{
PENERAPAN PENDIDIKAN KARAKTER PADA KEGIATAN EKSTRAKURIKULER MELALUI METODE PEMBIASAAN
}

\author{
A. Mustika Abidin \\ mustikaabidin@gmail.com \\ Program Studi Pendidikan Agama Islam \\ Institut Agama Islam Negeri (IAIN) Bone
}

\begin{abstract}
This research shows the importance of applying character education to extracurricular activities through habituation methods. Extracurricular activities are educational activities outside the subjects to assist the development of students according to their needs, potential, talents, and interests through activities specifically organized by capable educators or education staff who have authority in schools. Therefore, in order to accelerate the implementation of character education as a reflection of the implementation of national education goals, namely by applying character education into the curriculum of educational institutions or extracurricular activities through habituation methods that aim to develop potential, talent, interest, ability, personality, cooperation and independence optimally students who in the end have good character.
\end{abstract}

Keywords: Character Education, Extracurricular Activities, Habits

\section{PENDAHULUAN}

Keberhasilan suatu bangsa dalam mencapai tujuan nasional tidak hanya ditentukan oleh sumber daya alam yang melimpah ruah, akan tetapi juga ditentukan oleh sumber daya manusianya. Dalam kaitaannya dengan pendidikan karakter, bangsa Indonesia sangat memerlukan SDM (sumber daya manusia) yang besar dan bermutu untuk mendukung terlaksananya program pembangunan dengan baik. Untuk itu, dibutuhkan pendidikan yang 
berkualitas sehingga menghasilkan peserta didik yang unggul dan mendukung tercapainya cita-cita bangsa.

Pendidikan adalah usaha secara sadar dan terencana guna mencapai harapan agar peserta didik akan mendapatkan proses pembelajaran dan secara aktif mampu mengembangkan serta menyalurkan potensi dirinya agar memiliki moral yang baik meliputi keagamaan, akhlak yang mulia, kepribadian yang jujur dan bertanggung jawab, serta memiliki keterampilan yang nantinya akan berguna bagi dirinya maupun bagi masyarakat. Sebagaimana tertuang dalam UU SISDIKNAS No. 20 tahun 2003:

Pendidikan Nasional bertujuan untuk mengembangkan potensi peserta didik agar menjadi manusia beriman dan bertakwa kepada Tuhan Yang Maha Esa, berakhlak mulia, sehat, berilmu, cakap, kreatif, mandiri dan menjadi warga negara yang demokratis serta bertanggung jawab. Sedangkan visi yang diemban oleh pendidikan nasional adalah terwujudnya sistem pendidikan nasional sebagai pranata sosial yang kuat dan berwibawa untuk memberdayakan semua warga negara Indonesia berkembang menjadi manusia yang berkualitas sehingga mampu dan produktif menjawab tantangan zaman (Undang-Undang Republik Indonesia No 20 Tahun 2003 tentang Sistem Pendidikan Nasional SISDIKNAS, 2003: 7).

Berdasarkan tujuan pendidikan Nasional di atas, pada tahun 2010 pemerintah menggulirkan Kebijakan Nasional Pembangunan Karakter Bangsa, sehingga pengintegrasian (memasukkan) pendidikan karakter dalam kurikulum lembaga pendidikan adalah sebuah keharusan yang tidak bisa ditunda lagi.

Selain itu, perlu juga dipahami bahwa pendidikan karakter (character education) akhir-akhir ini merupakan suatu fenomena yang menarik untuk dikaji dan dianalisis baik ditinjau dari perspektif politik, birokrasi maupun ditinjau secara akademik. Secara birokratis, program 100 hari kementrian Pendidikan Nasional Republik Indonesia dalam kabinet Indonesia Bersatu jilid II telah melahirkan program strategis dengan menggagas penyelenggaraan pendidikan karakter dan budaya bangsa. Artinya, pendidikan karakter telah dijadikan sebagai misi pertama dari delapan misi guna mewujudkan visi pembangunan nasional dalam Rencana Pembangunan Jangka Panjang Nasional (RPJPN) Tahun 2005-2025 (Muhammad Yaumi, 2014: 3).

Pendidikan karakter menjadi isu penting dalam dunia pendidikan akhir-akhir ini, hal ini berkaitan dengan fenomena dekadensi moral yang terjadi ditengah-tengah masyarakat maupun di lingkungan pemerintah yang semakin meningkat dan beragam. Kriminalitas, ketidakadilan, korupsi, kekerasan pada anak, pelangggaran HAM, menjadi bukti bahwa telah terjadi krisis jati diri dan karakteristik pada bangsa Indonesia. Budi pekerti luhur, kesantunan, dan relegiusitas yang dijunjung tinggi dan menjadi budaya bangsa Indonesia 
selama ini seakan-akan menjadi terasa asing dan jarang ditemui ditengah-tengah masyarakat. Kondisi ini akan menjadi lebih parah lagi jika pemerintah tidak segera mengupayakan program-program perbaikan baik yang bersifat jangka panjang maupun jangka pendek. Pendidikan karakter menjadi sebuah jawaban yang tepat atas permasalahan-permasalahan yang telah disebut di atas dan sekolah sebagai penyelenggara pendidikan diharapkan dapat menjadi tempat yang mampu mewujudkan misi dari pendidikan karakter tersebut.

Pendidikan karakter merupakan pendidikan yang menanamkan dan mengembangkan karakter-karakter luhur kepada peserta didik, sehingga memiliki karakter luhur, menerapkan, dan mempraktikkan dalam kehidupannya, baik dalam keluarga, sebagai anggota masyarakat dan warga negara. Itulah sebabnya, penerapan pendidikan karakter menjadi sangat penting dalam perkembangan kepribadian dan keimanan peserta didik (Agus Wibowo, 2013: 400).

Keberhasilan pendidikan karakter merupakan hal yang utama dan menjadi landasan penting dalam dunia pendidikan untuk mendidik peserta didik. Bahkan dalam perkembangan sejarah ummat manusia, pendidikan karakter sebagai penyaring dan sebagai kontrol perkembangan peradaban modern yang berujung bebas nilai, jika tidak dilandasi dengan nilai-nilai Islam (Asmani Jamal Ma'mur, 2011: 54-55). Hal tersebut terilustrasikan pada kisah Luqman sebagaimana yang diperintahkan Allah swt. berdasarkan pada QS Luqman/31: 13 dengan terjemahan sebagai berikut:

Dan (ingatlah) ketika Luqman berkata kepada anaknya, di waktu ia memberi pelajaran kepadanya: "Hai anakku, janganlah kamu mempersekutukan Allah, sesungguhnya mempersekutukan (Allah) adalah benar-benar kezaliman yang besar" (Departemen Agama RI, 2007: 413).

Pentingnya nilai-nilai Islam sebagai landasan untuk membentuk karakter tergambar jelas pada ayat di atas. Pendidikan karakter akan berdampak pada akidah dan akhlak serta perilaku siswa di lingkungan sosial di masyarakat. Oleh karena itu, pendidikan yang berbasis nilai-nilai Islam yang dilakukan oleh orang tua dan guru di sekolah merupakan penentu dalam membentuk karakter beragama dan pergaulan sosial kemasyarakatan. Hal tersebut sebagaimana Rasullah saw. bersabda, sebagai berikut:

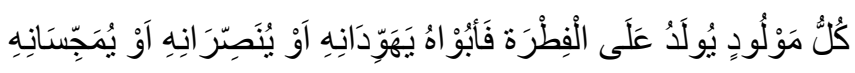

Artinya:

"Tiap-tiap anak dilahirkan di atas fitrah maka ibu dan ayahnyalah yang mendidiknya menjadi orang yang beragama Yahudi, Nasrani, dan Majusi" (HR, Bukhari) (Abu Abdillah Muhammad Bin Ismail Al-Bukhari, 2009: 35).

Untuk mempercepat pelaksanaan pendidikan karakter sebagai pencerminan dari pelaksanaan tujuan pendidikan nasional dan berdasarkan ayat serta hadis di atas adalah 
dengan cara mengintegrasikan pendidikan karakter kedalam kurikulum lembaga pendidikan. Pendidikan karakter dalam lembaga pendidikan sebenarnya telah dilaksanakan jauh sebelum didengungkannya Program Pendidikan Budaya dan Karakter Bangsa, tentunya dengan model yang dikembangkan sendiri oleh masing-masing lembaga diantaranya adalah melalui kegitan ekstrakurikuler. Pelaksanaan Kebijakan pemerintahan tersebut perlu dilihat secara langsung untuk mengetahui sejauh mana lembaga pendidikan melaksanakan implementasi pendidikan karakter tersebut. Berdasarkan Peraturan Menteri Pendidikan dan Kebudayaan Nomor 62 tahun 2014 tentang kegiatan ekstrakurikuler yang menyatakan bahwa:

Kegiatan ekstrakurikuler adalah kegiatan kurikuler yang dilakukan oleh peserta didik di luar jam pelajaran, di bawah bimbingan dan pengawasan satuan pendidikan, bertujuan untuk mengembangkan potensi, bakat, minat, kemampuan, kepribadian, kerjasama, dan kemandirian peserta didik secara optimal untuk mendukung pencapain tujuan pendidikan (Peraturan Menteri Pendidikan dan Kebudayaan Nomor 62 tahun 2014 tentang Kegiatan Ekstrakurikuler, 2014, 2)

Berdasarkan uraian di atas, dapat dipahami bahwa kegiatan ekstrakurikuler merupakan perangkat operasional kurikulum yang perlu disusun dan dituangkan dalam rencana kerja tahunan/kalender pendidikan satuan pendidikan. Dengan menerapkan pendidikan karakter melalui kegiatan ekstrakurikuler berbasis pembiasaan diharapkan menjembatani kebutuhan perkembangan peserta didik yang berbeda seperti perbedaan nilai moral dan sikap, kemampuan, dan kreativitas. Melalui partisipasinya dalam kegiatan ekstrakurikuler peserta didik dapat belajar dan memiliki karakter yang lebih baik.

\section{A. Pendidikan Karakter}

\section{Pengertian Pendidikan Karakter}

Pendidikan adalah usaha sadar dan terencana untuk mewujudkan suasana belajar dan proses pembelajaran agar peserta didik secara aktif mengembangkan potensi dirinya untuk memiliki kekuatan spiritual keagamaan, pengendalian diri, kepribadian, kecerdasan, akhlak mulia, serta ketrampilan yang diperlukan dirinya, masyarakat, bangsa dan Negara (UndangUndang Republik Indonesia No 20 Tahun 2003 tentang Sistem Pendidikan Nasional SISDIKNAS, 2003: 7) sedangkan karakter secara etimologi berasal dari bahasa Latin "character", yang berarti watak, tabiat, sifat-sifat kejiwaan, budi pekerti, kepribadian dan akhlak (Musfah, 2011: 127). Karakter adalah sifat kejiwaan, akhlak, atau budi pekerti yang menjadi ciri khas seseorang kelompok orang. Karakter merupakan nilai-nilai yang berhubungan dengan Tuhan Yang Maha Esa, diri sendiri, sesama manusia, lingkungan dan kebangsaan yang terwujud dalam pikiran, sikap, perasaan, perkataan, dan perbuatan 
berdasarkan norma-norma agama, hukum, tata krama, budaya dan adat istiadat (Agus Zainul Fitri, 2012: 20-21).

Pendidikan karakter adalah suatu usaha untuk membentuk kebiasaan baik anak sejak dini, atau suatu sistem penanaman nilai-nilai karakter yang meliputi komponen pengetahuan, kesadaran atau kemauan, dan tindakan untuk meleksanakan nilai-nilai tersebut, baik terhadap Tuhan Yang Maha Esa, diri sendiri, sesama, lingkungan, maupun kebangsaan sehingga menjadi insan kamil (Ratna Megawani, 2010: 23). Pendidikan karakter juga dapat dimaknai sebagai upaya yang sungguh-sungguh dengan cara cirri kepribadian positif dikembangkan, didorong dan diberdayakan melalui keteladanan, kajian (sejarah dan biografi pra bijak dan pemikir besar), serta praktik emulasi (usaha yang maksimal untuk mewujudkan hikmah dari apa-apa yang dipelajari) (Muclas samani \& Hariyanto, 2012: 2). Selain itu, pendidikan karakter mengandung makna diberikannya tempat bagi kebebasan individu dalam mennghayati nilai-nilai yang dianggap sebagai baik, luhur, dan layak diperjuangkan sebagai pedoman bertingkah laku bagi kehidupan pribadi berhadapan dengan dirinya, sesame manusia dan Allah swt. (Doni Koesoema, 2010: 5).

Dengan demikian, pendidikan karakter merupakan upaya penanaman/ pembentukan kecerdasan seseorang dalam berpikir, penghayatan dalam bentuk sikap, dan pengamalan dalam bentuk perilaku yang sesuai dengan nilai-nilai yang luhur yang menjadikan untuk jati dirinya, diwujudkan dengan interaksi kepada Tuhan-Nya, diri sendiri, antar sesama, dan lingkunganya. Begitu pentingnya pendidikan karakter, maka penanaman atau pembentukan pendidikan karakter tidak hanya diberikan secara teori melalui sekedar menstransfer ilmu saja, melainkan harus dilakukan secara praktek dengan memberikan contoh teladan yang baik serta pembiasaan atau pembudayaan kepada peserta didik dalam lingkungan sekolah, keluarga, dan masyarakat.

\section{Tujuan Pendidikan Karakter}

Pendidikan karakter bertujuan untuk meningkatkan mutu penyelenggaraan dan hasil pendidikan yang mengarah pada pencapaian pembentukan karakter atau akhlak mulia peserta didik secara utuh, terpadu, dan seimbang, sesuai standar kompetensi lulusan. Melalui pendidikan karakter diharapkan peserta didik mampu secara mandiri meningkatkan dan menggunakan pengetahuannya, mengkaji dan menginternalisasi serta mempersonalisasi nilai-nilai karakter dan akhlak mulia sehingga terwujud dalam perilaku sehari-hari. Pendidikan karakter bertujuan membentuk dan membangun pola pikir, sikap, dan perilaku peserta didik agar menjadi pribadi yang positif, berakhlak karimah, berjiwa luhur dan 
bertanggung jawab (Agus Zainul Fitri, 2012: 22) sedangkan dari segi pendidikan, pendidikan karakter bertujuan untuk meningkatkan mutu penyelenggaraan dan hasil pendidikan yang mengarah pada pencapaian pembentukan karakter dan akhlak mulia peserta didik secara utuh, terpadu dan seimbang (Masnur Muslih, 2011: 81).

Menurut Kementerian Pendidikan Nasional, tujuan pendidikan karakter antara lain: (a) Mengembangkan potensi peserta didik agar menjadi manusia yang berhati baik, berpikiran baik, dan berperilaku baik,(b) Membangun peserta didik yang berkarakter pancasila dan religious serta memiliki tanggung jawab sebagai generasi penerus bangsa, (c) Mengembangkan kemampuan peserta didik untuk menjadi manusia yang mandiri, kreatif, dan berwawasan kebangsaan,(d) Mengembangkan lingkungan kehidupan sekolah sebagai lingkungan belajar yang aman, jujur penuh kreativitas dan persahabatan, serta dengan rasa kebangsaan yang tinggi dan penuh kekuatan (Kemendiknas, 2011: 5).

Dengan demikian, tujuan dari pendidikan karakter adalah membentuk nilai-nilai positif pada peserta didik sehingga menjadi manusia yang unggul dan berkualitas. Sehingga, untuk mewujudkan tujuan tersebut, peran keluarga, sekolah dan masyarakat sangat menentukan pembangunan karakter anak-anak untuk kehidupan yang lebih baik di masa mendatang karena dengan menciptakan lingkungan yang kondusif, anak-anak akan tumbuh menjadi pribadi yang berkarakter sehingga fitrah setiap anak yang dilahirkan suci dapat berkembang secara optimal.

\section{B. Kegiatan Ekstrakurikuler}

\section{Pengertian Kegiatan Ekstrakurikuler}

Kegiatan ekstrakurikuler berdasarkan Peraturan Menteri Pendidikan dan Kebudayaan Nomor 62 tahun 2014 menyatakan bahwa kegiatan ekstrakurikuler adalah kegiatan kurikuler yang dilakukan oleh peserta didik di luar jam pelajaran, di bawah bimbingan dan pengawasan satuan pendidikan, bertujuan untuk mengembangkan potensi, bakat, minat, kemampuan, kepribadian, kerjasama, dan kemandirian peserta didik secara optimal untuk mendukung pencapain tujuan pendidikan (Peraturan Menteri Pendidikan dan Kebudayaan Nomor 62 tahun 2014 tentang Kegiatan Ekstrakurikuler, 2014, 2).

Kegiatan ekstrakurikuler merupakan kegiatan yang dilakukan di luar jam pelajaran biasa, pada waktu libur, di dalam maupun di luar sekolah yang secara rutin atau hanya pada waktu tertentu dilakukan saja sesuai dengan kemampuan sekolah (Hadiyanto, 2009: 151). Kegiatan ekstrakurikuler adalah kegiatan di luar jam pelajaran biasa (termasuk pada waktu hari libur) yang di lakukan di sekolah ataupun di luar sekolah yang bertujuan untuk 
memperluas pengetahuan peserta didik mengenai hubungan antara berbagai mata pelajaran, menyalurkan bakat dan minat serta melengkapi upaya pembinaan manusia seutuhnya (Sahertian, 2010: 132).

Kegiatan ekstrakurikuler merupakan bagian internal (penting) dari proses pembelajaran yang menekankan pada pemenuhan kebutuhan peserta didik karena kegiatan intrakurikuler dan ekstrakurikuler merupakan kegiatan yang tidak dapat dipisahkan, bahkan kegiatan ekstrakurikuler merupakan perpanjangan pelengkap atau penguatan kegiatan intrakurikuler untuk menyalurkan bakat dan menjadi pendorong perkembangan potensi peserta didik untuk mencapai taraf maksimum atau menjadi lebih baik (Rusli Lutan, 2010: 72). Kegiatan ekstrakurikuler adalah kegiatan pendidikan yang dilaksanakan diluar jam pelajaran intrakurikuler (di dalam kelas) yang tujuannya untuk membantu mengembangkan kemampuan peserta didik sesuai dengan kebutuhan, potensi, bakat dan minat melalui kegiatan yang secara khusus diselenggarakan oleh pendidik maupun tenaga kependidikan yang memiliki kewenangan atau kemampuan di sekolah/madrasah (Muhaimin dkk, 2008: 74).

Dengan demikian, kegiatan ekstrakurikuler merupakan kegiatan yang dilaksanakan diluar jam pelajaran wajib. Kegiatan ini bertujuan untuk memperdalam dan memperkaya pengatahuan peserta didik, mengenal hubungan antara berbagai materi pelajaran, memberikan keleluasaan kepada peserta didik untuk memilih kegiatan sesuai dengan bakat dan minatnya, memperkaya dan memperluas diri yaitu dengan memperluas wawasan pengetahuan dan mendorong pembinaan sikap atau nilai-nilai positif.

\section{Tujuan dan Fungsi Kegiatan Ekstrakurikuler}

Pengembangan kegiatan ekstrakurikuler merupakan bagian dari keseluruhan pengembangan institusi suatu sekolah. Berbeda dari pengaturan kegiatan intrakurikuler yang secara jelas disiapkan dalam perangkat kurikulum sedangkan kegiatan ekstrakurikuler lebih mengandalkan inisiatif dari pihak sekolah atau madrasah. Secara yuridis, pengembangan kegiatan ekstrakurikuler memiliki landasan hukum yang kuat karena diatur dalam surat Peraturan Menteri Pendidikan dan Kebudayaan Nomor 62 tahun 2014 pada Pasal 2, yaitu:

Kegiatan ekstrakurikuler diselenggarakan dengan tujuan untuk mengembangkan potensi, bakat, minat, kemampuan, kepribadian, kerjasama, dan kemandirian peserta didik secara optimal dalam rangka mendukung pencapaian tujuan pendidikan nasional (Peraturan Menteri Pendidikan dan Kebudayaan Nomor 62 tahun 2014 tentang Kegiatan Ekstrakurikuler, 2014, 2). 
Kegiatan ekstrakurikuler merupakan seperangkat pengalaman belajar memiliki nilainilai bagi pembentukan kepribadian siswa. Adapun tujuan dari pelaksanaan kegiatan ekstrakurikuler antara lain: (a) Kegiatan ekstrakurikuler dapat meningkatkan kemampuan peserta didik untuk memiliki kecerdasan kognitif, afektif, dan psikomotor, (b) Mengembangkan bakat dan minat peserta didik dalam upaya pembinaan pribadi menuju pembinaan manusia seutuhnya yang positif, dan (c) Dapat mengetahui, mengenal serta membedakan antara hubungan satu pelajaran dengan mata pelajaran lainnya, sedangkan fungsi dari fungsi kegiatan ekstrakurikuler (a) pengembangan, yaitu untuk mengembangkan potensi, bakat dan minat peserta didik, (b) Social, yaitu untuk mengembangkan kemampuan dan tanggung jawab sosial peserta didik, (c) Rekreatif, yaitu ler untuk mengembangkan suasana rileks, menggembirakan dan menyenangkan bagi peserta didik yang menunjang proses perkembangan, (d) Persiapan karier, yaitu untuk mengembangkan kesiapan karier peserta didik di masa depan (Oteng Sutrisno, 2011: 25).

Tujuan dari kegiatan ekstrakurikuler sebagai berikut: (a) Meningkatkan kompetensi peserta didik dalam aspek kognitif, afektif, dan psikomotorik, (b) Mengembangkan bakat dan minat peserta didik dalam upaya pembinaan pribadi menuju pembinaan manusia seutuhnya yang positif, (c) Memacu kemampuan mandiri, percaya diri, dan kreativitas, (d) Memperdalam dan memperluas pengetahuan peserta didik. Maksudnya yaitu memperkaya, mempertajam, serta memperbaiki pengetahuan peserta didik berkaitan dengan mata pelajaran sesuai dengan kegiatan ekstrakurikuler yang ada, (e) Meningkatkan kualitas keimanan dan ketakwaan kepada Allah swt., (f) Meningkatkan kesadaran berbangsa dan bernegara, dan (g) Membina budi pekerti yang luhur, sedangkan fungsi kegiatan ekstrakurikuler yaitu untuk mengaitkan pengetahuan yang diperoleh dalam program kurikulum dengan keadaan dan kebutuhan lingkungan serta usaha pemantapan dan pembentukan kepribadian peserta didik agar memiliki kemampuan untuk mandiri, percaya diri dan kreatif (Novan Ardy Wiyani, 2013: 106-107).

Dengan demikian, dapat dipahami bahwa sebagai kegiatan penunjang, kegiatan ekstrakurikuler tidak hanya terbatas pada program untuk membantu ketercapaian tujuan kurikuler saja, tetapi mencakup pemantapan dan pembentukan kepribadian yang utuh termasuk pengembangan minat dan bakat peserta didik. Dengan demikian program kegiatan ekstrakurikuler harus dirancang sedemikian rupa sehingga dapat menunjang kegiatan kurikuler, maupun pembentukan kepribadian yang menjadi inti kegiatan ekstrakurikuler. 


\section{Metode Pembiasaan}

\section{Pengertian Metode Pembiasaan}

Secara etimologi, pembiasaan asal katanya adalah biasa. Dalam kamus bahasa Indonesia biasa adalah lazim atau umum, seperti sedia kala, sudah merupakan yang tidak terpisahkan dari kehidupan sehari-hari. Dengan adanya prefiks pe- dan sufiks -an menunjukan arti proses, sehingga pembiasaan dapat diartikan dengan proses membuat sesuatu/seseorang menjadi terbiasa. Dalam kaitannya dengan metode pengajaran, dapat dikatakan bahwa pembiasaan adalah sebuah cara yang dapat dilakukan untuk membiasakan peserta didik berfikir, bersikap dan bertindak sesuai dengan tuntunan yang berlaku (Armai Arief, 2012: 22).

Metode pembiasaan merupakan kegiatan yang dilakukan secara berulang-ulang agar sesuatu tersebut dapat menjadi kebiasaan. Metode pembiasaan adalah segala sesuatu yang dilakukan secara berulang untuk membiasakan individu dalam bersikap, berperilaku, dan berpikir dengan benar. Dalam proses pembiasaan berintikan pengalaman, sedangkan yang dibiasakan adalah sesuatu yang diamalkan (Anis Ibnatul M, dkk, 2013: 15).

Metode pembiasaan adalah suatu cara yang dapat dilakukan untuk membiasakan anak berfikir, bersikap, bertindak. Metode ini sangat praktis dalam pembinaan dan pembentukan karakter anak dalam meningkatkan pembiasaan-pembiasaan dalam melaksanakan suatu kegiatan. Hakikat pembiasaan sebenarnya berintikan pengalaman. Pembiasaan adalah sesuatu yang diamalkan. Oleh karena itu, uraian tentang pembiasaan selalu menjadi satu rangkaian tentang perlunya melakukan pembiasaan-pembiasaan yang dilakukan disetiap harinya. Inti dari pembiasaan adalah pengulangan. Dalam pembinaan sikap, metode pembiasaan sangat efektif digunakan karena akan melatih kebiasaankebiasaan yang baik kepada anak. Pembiasaan merupakan penanaman kecakapan-kecakapan berbuat dan mengucapkan sesuatu, agar cara-cara yang tepat dapat disukai oleh anak. Pembiasaan pada hakikatnya mempunyai implikasi yang lebih mendalam daripada penanaman cara-cara berbuat dan mengucapkan (Muhammad Fadlillah dan Lilif Mualifatu Khorida, 2013: 173).

Dalam kehidupan sehari-hari, pembiasaan merupakan hal yang penting, karena banyak dijumpai orang berbuat dan berperilaku hanya karena kebiasaan semata-mata. Pembiasaan mendorong agar mempercepat perilaku dan tanpa pembiasaan hidup seseorang akan berjalan lamban, sebab sebelum melakukan sesuatu harus memikirkan terlebih dahulu apa yang akan dilakukannya. Metode pembiasaan perlu diterapkan oleh guru dalam proses 
pembentukan karakter, untuk membiasakan peserta didik memiliki karakter yang baik sehingga aktivitas yang dilakukan oleh peserta didik terekam secara positif (E.Mulyasa dan Dewi Ispurwanti, 2013: 166).

Dengan demikian, metode pembiasaan merupakan proses kegiatan yang dilakukan secara berulang-ulang yang bertujuan untuk membuat individu menjadi terbiasa dalam bersikap, berperilaku dan berpikir sesuai dengan tujuan yang telah ditetapkan. Tujuan dari proses pembiasaan di sekolah maupun dikegiatan ekstrakurikuler adalah untuk membentuk sikap dan perilaku peserta didik yang relatif menetap karena dilakukan secara berulangulang baik di kegiatan intrakurikuler maupun kegiatan ekstrakurikuler.

\section{Dasar dan Tujuan Metode Pembiasaan}

Pembiasaan merupakan salah satu metode pendidikan yang sangat penting, terutama bagi anak. Seorang anak belum memahami/menginsafi apa yang disebut baik dan buruk dalam arti susila, mereka juga belum mempunyai kewajiban-kewajiban yang harus dikerjakan seperti pada orang dewasa. Sehingga perlu dibiasakan dengan tingkah laku, keterampilan, kecakapan, dan pola pikir tertentu. Anak perlu dibiasakan pada sesuatu yang baik. Lalu akan mengubah seluruh sifat-sifat baik menjadi kebiasaan, sehingga jiwa dapat menunaikan kebiasaan itu tanpa terlalu payah, tanpa kehilangan banyak tenaga, dan tanpa menemukan banyak kesulitan (Abudin Nata, 2010: 10).

Dalam teori perkembangan peserta didik, dikenal adanya teori konvergensi, dimana pribadi dapat dibentuk oleh lingkungannya dan dengan mengembangkan potensi dasar yang ada pada dirinya. Potensi dasar ini dapat menjadi penentu tingkah laku yang tentunya dengan melalui proses. Oleh karna itu potensi dasar harus selalu diarahkan agar tujuan pendidikan dapat tercapai dengan baik. Salah satu cara yang dapat dilakukan dalam mengembangkan potensi dasar tersebut adalah melalui kebiasaan yang baik atau pembiasaan.

Tujuan utama dari pembiasaan adalah penanaman kecakapan-kecakapan berbuat dan mengucapkan sesuatu, agar cara-cara yang tepat dapat dikuasai oleh peserta didik, dan perbuatan-perbuatan tersebut dapat dibiasakan dan sulit untuk ditinggalkan. Tujuan diadakannya metode pembiasaan adalah untuk melatih serta membiasakan peserta didik secara konsisten dan continue dengan sebuah tujuan, sehingga benar-benar tertanam dalam diri peserta didik dan akhirnya menjadi kebiasaan yang sulit ditinggalkan dikemudian hari (Ahmad D Marimba, 2011: 82). 
Dengan demikian, metode pembiasaan adalah proses pembentukan kebiasaankebiasaan baru atau perbaikan kebiasaan-kebiasaan yang telah ada. Belajar kebiasaan, selain menggunakan perintah, suri tauladan dan pengalaman khusus juga menggunakan hukuman dan ganjaran. Tujuannya agar speserta didik memperoleh sikap, kebiasaan, dan perbuatan baru yang lebih tepat dan positf dalam arti selaras dengan kebutuhan ruang dan waktu (kontekstual).

\section{Syarat-syarat Pelaksanaan Metode Pembiasaan}

Metode pembiasaan ini mendorong dan memberikan ruang kepada peserta didik pada teori-teori yang menumbuhkan aplikasi langsung, sehingga teori yang berat menjadi ringan bagi peserta didik bila kerap kali dilaksanakan. Adapun syarat-syarat yang harus dilakukan dalam melaksanakan metode pembiasaan itu antara lain:

a. Mulailah pembiasaan sebelum terlambat. Usia sejak bayi dinilai waktu yang sangat tepat untuk mengaplikasikan pendekatan ini, karena setiap anak mempunyai rekaman yang cukup kuat dalam menerima pengaruh lingkungan sekitarnya dan secara langsung akan dapat membentuk kepribadian seorang anak. Kebiasaan positif maupun negatif akan muncul sesuai dengan lingkungan yang membentuknya (mulailah pembiasaan itu sebelum terlambat, jadi sebelum anak itu mempunyai kebiasaan lain yang berlawanan dengan hal-hal yang akan dibiasakan).

b. Pembiasaan hendaklah dilakukan secara kontinu (berulang-ulang, teratur dan berprogram) sehingga pada akhirnya akan terbentuk sebuah kebiasaan yang utuh, permanen dan konsisten. Oleh karena itu faktor pengawasan sangat menentukan dalam pencapaian keberhasilan dari proses ini.

c. Pembiasaan hendaknya diawasi secara ketat, konsisten dan tegas. Jangan memberi kesempatan yang luas kepada peserta didik untuk melanggar kebiasaan yang telah ditanamkan.

d. Pembiasaan yang pada mula hanya bersifat mekanistis, hendaknya secara berangsurangsur dirubah menjadi kebiasaan yang tidak verbalistik dan menjadi kebiasaan yang disertai dengan kata hati anak didik itu sendiri (Ulil Amri Syafri, 2012: 140).

Dengan demikian, dari uraian di atas, dapat dipahami bahwa indikator metode pembiasaan itu adalah suatu cara atau jalan yang dilakukan dengan sengaja, berulang-ulang, terus-menerus, konsisten, berkelanjutan, untuk menjadikan sesuatu itu kebiasaan (karakter) yang melekat pada diri sang anak, sehingga nantinya anak tidak memerlukan pemikiran lagi untuk melakukannya. 


\section{Kelebihan dan Kelemahan Metode Pembiasaan}

Sebagai suatu metode, pembiasaan juga memiliki kelebihan dan kelemahan. Adapun kelebihan metode pembiasaan antara lain: (1) Dapat menghemat tenaga dan waktu dengan baik, (2) Pembiasaan tidak hanya berkaitan dengan aspek lahiriyah tapi juga berhubungan dengan aspek batiniyah, (3) Pembiasaan dalam sejarah tercatat sebagai metode yang paling berhasil dalam pembentukan kepribadian anak didik.

Adapun kelemahan dalam metode pembiasaan antara lain: (1) Membutuhkan tenaga pendidik yang benar-benar dapat dijadikan contoh sera teladan bagi anak didik, (2) Membutuhkan pendidik yang dapat mengaplikasikan antar teori pembiasaan dengan kenyataan-kenyataan atau praktek nilai-nilai yang disampaikan. (Armai Arief, 2012: 22).

\section{Penerapan Pendidikan Karakter Melalui Kegiatan Ekstrakurikuler Berbasis Pembiasaan}

Konsep umum pendidikan merujuk pad suatu upaya untuk meningkatkan kecerdasan, keterampilan, dan pengembangan potensi diri serta pembentukan pribadi yang memiliki akhlak mulia serta karakter yang baik. Dalam hal ini, pendidikan memainkan peran yang penting dalam membentuk pribadi yang tidak hanya cerdas, tetapi juga berkarakter baik. Untuk itu, diharapkan dengan adanya pendidikan mampu melahirkan pribadi yang berakhlak mulia ataupun berkarakter baik ini mendorong pihak sekolah untuk melaksanakan berbagai hal demi mewujudkan tujuan tersebut.

Kegiatan ekstrakurikuler adalah kegiatan pendidikan di luar mata pelajaran untuk membantu pengembangan peserta didik sesuai dengan kebutuhan, potensi, bakat, dan minat melalui kegiatan yang secara khusus diselenggarakan oleh pendidik atau tenaga kependidikan yang berkemampuan dan memiliki kewenangan di sekolah. Pelaksanaan kegiatan ekstrakurikuler ini bertujuan agar dapat meningkatkan kemapuan peserta didik baik kemampuan kognitif, afektif maupun psikomotorik. Perlu dipahami juga bahwa kegiatan ekstrakurikuler dilaksanakan agar dapat mengembangkan bakat dan minat peserta didik dalam upaya pembinaan pribadi menuju pembinaan manusia seutuhnya yang positif melalui metode pembiasaan. Tujuan kegiatan ekstrakurikuler ini sacara jelas memberikan gambaran bahwa pendidikan karakter peserta didik pada kegiatan ekstrakurikuler perlu dibina dan dibangun secara baik. 


\section{PENUTUP}

Pendidikan Nasional bertujuan untuk mengembangkan potensi peserta didik agar menjadi manusia beriman dan bertakwa kepada Tuhan Yang Maha Esa, berakhlak mulia, sehat, berilmu, cakap, kreatif, mandiri dan menjadi warga negara yang demokratis serta bertanggung jawab. Sedangkan visi yang diemban oleh pendidikan nasional adalah terwujudnya sistem pendidikan nasional sebagai pranata sosial yang kuat dan berwibawa untuk memberdayakan semua warga negara Indonesia berkembang menjadi manusia yang berkualitas sehingga mampu dan produktif menjawab tantangan zaman. Sehingga, untuk mempercepat pelaksanaan pendidikan karakter sebagai pencerminan dari pelaksanaan tujuan pendidikan nasional adalah dengan cara menerapkan pendidikan karakter kedalam kurikulum lembaga pendidikan atau kegiatan ekstrakurikuler melalui metode pembiasaan yang bertujuan untuk mengembangkan potensi, bakat, minat, kemampuan, kepribadian, kerjasama, dan kemandirian peserta didik secara optimal.

\section{DAFTAR PUSTAKA}

Arief, Armai. 2012. Pengantar Ilmu dan Metodologi Pendidikan Islam. Jakarta: Ciputat Pers.

Bukhari, Imam \& Imam Muslim; Disusun oleh Ahmad Ali, Lc. 2012. Kitab Shahih Al-Bukhari dan Muslim: Referensi Hadis Sepanjang Masa. Cet.I; Depok: Alita Aksara Media.

Departemen Agama RI. 2007. Al-Qur'an \& Terjemahnya. Jakarta: Yayasan Penyelenggara Penerjemah/Penafsir Al-Qur'an Revisi Terjemah oleh Lajnah Pentashih Mushaf Al-Qur'an.

Fadlillah, Muhammad \& Lilif Mualifatu Khorida.. 2013. Pendidikan Karakter Anak Usia Dini: Konsep dan Aplikasinya dalam PAUD, Jogjakarta: Ar-Ruzz Media.

Fitri, Agus Zainul. 2012. Pendidikan Karakter Berbasis Nilai \& Etika di Sekolah. Yogyakarta: Ar-Ruz Media.

Ibnatul M, Anis. 2013. Panduan Internalisasi Pendidikan Karakter di Sekolah. Yogyakarta: UNES.

Kemendiknas. 2011. Kebijakan dan Implementasi Pendidikan Karakter Bangsa Pada Satuan Pendidikan, Direktorat Jendral PTK Dikmen Kementrian Pendidikan Nasional. 
Koesoema, Doni. 2010. Pendidikan Karakter Strategi Mendidik Anak di Zaman Global. Jakarta: PT.Grasindo.

Lutan, Rusli. 2010. Interaksi Kegiatan Intrakurikuler, Ko-kurikuler dan Ekstrakurikuler, Bandung: Depdikbud.

Ma'mur, Asmani Jamal. 2011. Buku Panduan Internalisasi Pendidikan Karakter di Sekolah. Jogjakarta: DIVA Press.

Marimba, Ahmad D. 2010. Pengantar Filsafat Pendidikan Islam. Bandung: PT. Al Ma'arif.

Megawani, Ratna. 2010. Pendidikan Karakter Solusi yang Tepat untuk Membangun Bangsa. Cet.II; Bogor.

Menteri Pendidikan dan Kebudayaan Republik Indonesia, Peraturan Menteri Pendidikan dan Kebudayaan Nomor 62 tahun 2014 tentang Kegiatan Ekstrakurikuler, Jakarta.

Muhaimin dkk, 2008. Pengembangan Model KTSP Pada Sekolah dan Madrasah. Jakarta: PT Raja Grapindo Persada.

Mulyasa, E. \& Dewi Ispurwanti. 2013. Manajemen Pendidikan Karakter. Jakarta: Bumi Aksara.

Musfah. 2011. Pendidikan Karakter: Sebuah Tawaran Model Pendidikan. Jakarta: Prenada Media.

Muslih, Masnur. 2011. Pendidikan Karakter Menjawab Tantangan Krisis Multidimensional. Jakarta: Bumi Aksara.

Nata, Abudin. 2010. Filsafat Pendidikan Islam. Jakarta: Logos Wacana Ilmu.

Sahertian. 2010. Dimensi Administrasi Pendidikan. Surabaya: Usaha Nasional.

Samani, Muclas \& Hariyanto. 2012. Pendidikan Karakter Konsep dan Model, Bandung: Alfabeta.

Sutrisno, Oteng. 2011. Administrasi Pendidikan, Dasar Retorika untuk Praktek Profesional. Bandung: Angkasa.

Syafri, Ulil Amri. 2012. Pendidikan Karakter Berbasis Al-Qur"an. Jakarta: Rajawali Pers.

Undang-Undang Republik Indonesia No 20 Tahun 2003 tentang Sistem Pendidikan Nasional (SISDIKNAS) Beserta Penjelasannya. Bandung: Citra Umbara.

Wibowo, Agus. 2013. Pendidikan Karakter. Yogyakarta: Pustaka Pelajar.

Wiyani, Novan Ardy. 2013. Konsep, Praktik, dan Strategi Membumikan Pendidikan Karakter di SD. Jogjakarta: Ar-Ruzz Media.

Yaumi, Muhammad. 2014. Pendidikan Karakter: Landasan, Pilar dan Implementasi .Cet.I; Jakarta: Kencana. 